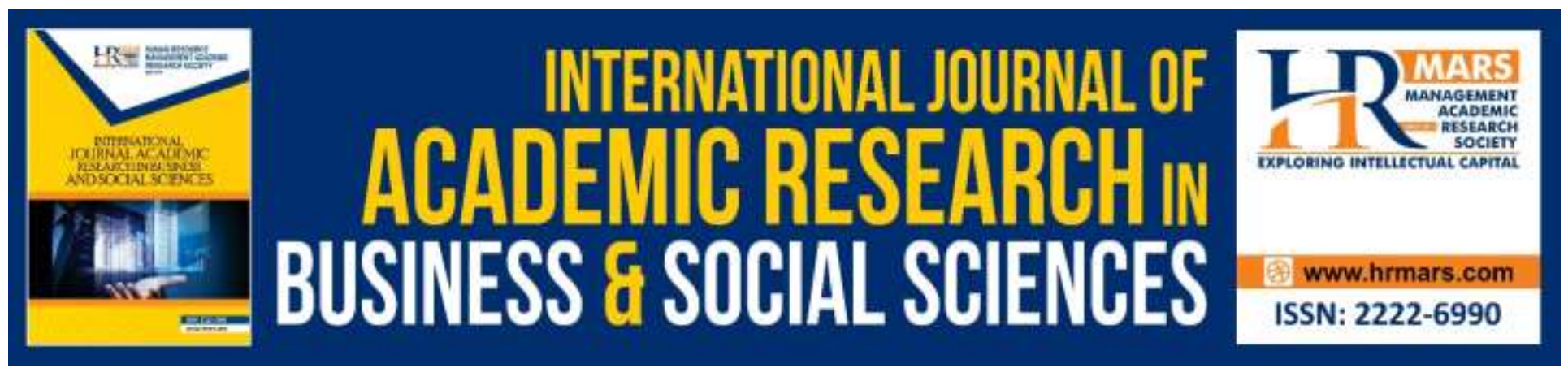

\title{
Do Women Buy Online Impulsively More Often Out of Enjoyment and Risk Tolerance?
}

\author{
Shathees Baskaran, Tai Mee Yuen, Zawiyah Mahmood, Nomahaza Mahadi \\ and Bathmavathy Dalayga
}

To Link this Article: http://dx.doi.org/10.6007/IJARBSS/v9-i7/6094

DOI: 10.6007/IJARBSS/v9-i7/6094

Received: 12 May 2019, Revised: 19 June 2019, Accepted: 29 June 2019

Published Online: 25 July 2019

In-Text Citation: (Baskaran, Yuen, Mahmood, Mahadi, \& Dalayga, 2019)

To Cite this Article: Baskaran, S., Yuen, T. M., Mahmood, Z., Mahadi, N., \& Dalayga, B. (2019). Do Women Buy Online Impulsively More Often Out of Enjoyment and Risk Tolerance? International Journal of Academic Research in Business and Social Sciences, 9(7), 88-107.

\section{Copyright: (C) 2019 The Author(s)}

Published by Human Resource Management Academic Research Society (www.hrmars.com)

This article is published under the Creative Commons Attribution (CC BY 4.0) license. Anyone may reproduce, distribute, translate and create derivative works of this article (for both commercial and non-commercial purposes), subject to full attribution to the original publication and authors. The full terms of this license may be seen

at: http://creativecommons.org/licences/by/4.0/legalcode

Vol. 9, No. 7, 2019, Pg. 88 - 107

http://hrmars.com/index.php/pages/detail/IJARBSS

JOURNAL HOMEPAGE

Full Terms \& Conditions of access and use can be found at http://hrmars.com/index.php/pages/detail/publication-ethics 


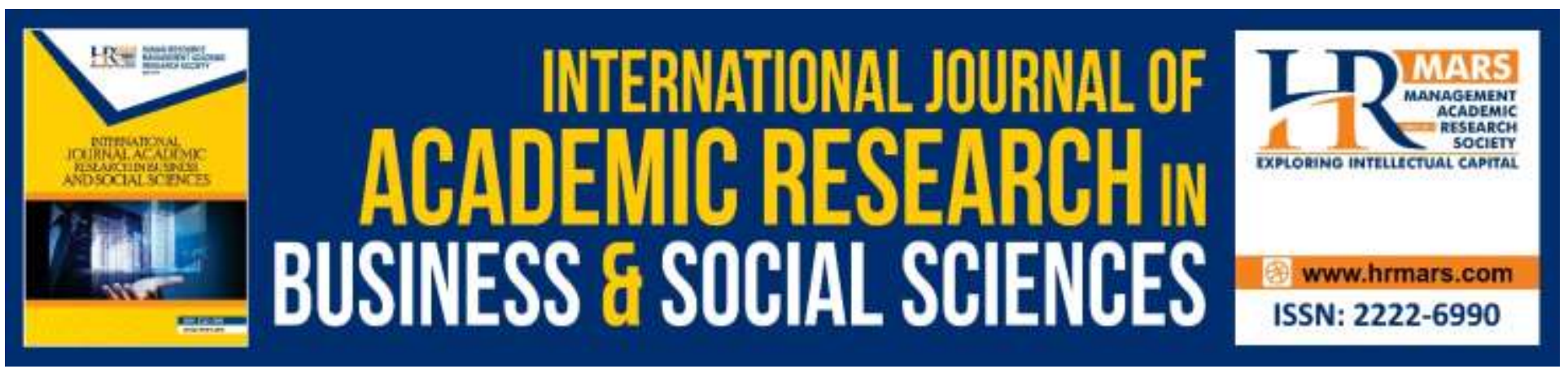

\title{
Do Women Buy Online Impulsively More Often Out of Enjoyment and Risk Tolerance?
}

\author{
Shathees Baskaran, Tai Mee Yuen, Zawiyah Mahmood, Nomahaza \\ Mahadi and Bathmavathy Dalayga \\ International Business School, Level 10, Menara Razak, Universiti Teknologi Malaysia, Jalan Sultan \\ Yahya Petra, 54100 Kuala Lumpur. \\ Email: shathees@utm.my
}

\begin{abstract}
The rapid growth of technology advancement in Malaysia enabled Malaysian consumers to browse and purchase products or services from online stores. Consequently, the shopping trend has been changing significantly from the physical store to online stores. Therefore, it is important to identify the determinants of the consumers online purchase intention. The objective of this research is to examine the relationship between impulsive buying tendency and perceived risk towards online purchase intention among Malaysian women. In order to investigate this relationship further, the mediating effect of shopping enjoyment was examined on the relationship between impulsive buying tendency and perceived risk towards online purchase intention among women online buyers in Malaysia. The study employed an online survey among women in Malaysia and the data was analyzed with SPSS. The results indicated that only impulsive buying tendency to be significant while the perceived risk was insignificant. Additionally, a partial mediation of shopping enjoyment was found between impulsive buying tendency and online purchase intention only and the same for perceived risk was unable to be retained. This findings have further supported the Theory of Planned Behaviour which claim that human will analyze the available information on hand and make a logical, reasoned decision to engage in specific behaviors. In this study, it was proven that consumers will make an impulsive purchase with the stimulation effect of shopping enjoyment. The research also discussed theoretical and managerial implications and ended with suggestions for future research.
\end{abstract}

Keywords: Shopping Enjoyment, Online Purchase Intention, Perceived Risk, Impulsive Buying Tendency, Electronic Commerce

\section{Introduction}

In the century driven by technological advancements, anyone can get information from the internet easily. This has transformed many business activities into more convenient and informative platforms to reach their target customers. Online purchase or online shopping is one of the examples whereby retailer transfers their physical retail store to the online platform and all transaction will be 
completed through internet which is more cost saving, time-saving, convenient and able to reach more customers. According to Internet World Statistics Usage and Population Statistics (2017), the internet user of Malaysia has increased from 3.7 million in 2000 to 24.5 million in 2017 (i.e. 78 percent penetrated total Malaysia's population in 2017). A total of 19 million Malaysians are Facebook users in 2017 (Statistics, 2017). The rapid growth of Internet users in Malaysia shows that Malaysian consumers tend to browse more information from the internet before they purchase products or services from web-retailers.

However, the Ministry of International Trade and Industry reported that e-commerce contributes only 5.8 percent GDP of Malaysia in 2016 (Mottain, 2017). This data shows that e-commerce in Malaysia is far away compared with China which has achieved 21 percent. There is about 48 percent of Malaysian consumers reported to perform online purchases monthly, however, is below the average percentage in South-East Asia's of 55 percent. China is reported the highest in Asia which presents 91 percent (Mottain, 2017). Nevertheless, according to Internet Users Survey (2016), the percentage of internet users for online shopping has decreased by $2.7 \%$ from 2014 to 2015 . One of the reasons is that about 38.5 percent of internet users still felt insecure about online shopping. There are only 35.3 percent of internet users in Malaysia engaging in online shopping while 54.6 percent of internet users are never done online purchase in the past. Another 10.2 percent of internet users only have experience browsing some online retails but never purchase anything from e-commerce so far (Internet Users Survey, 2016).

Another interesting finding from the Internet Users Survey (2016), is that women display a strong preference in having things done online. 44.9 percent of women purchase online compared to men who contribute to only 28.7 percent compared to internet users within the same cohort. In terms of internet banking service, 40 percent of women claimed that they performed online banking frequently compared to male accounting for only 33.4 percent. In discussing the adoption rate of social networking, women had achieved 81 percent while men resulted at 78.4 percent. Besides, women prefer to obtain all kind of information via the internet if compared with men, and that is one of the reasons why female represented 51.7 percent of online shoppers and male represents only 48.3 percent of total internet users in Malaysia.

From the data presented above, it is evident that e-commerce in Malaysia still underdeveloped and there is much room to grow in the future. Additionally, gender also plays a significant role in online buying behavior. Hence, it is the aim of this study to identify the determinants of online purchase intention among women in Malaysia. Thus, the research will examine the relationship between the impulsive buying tendency, perceive risk and shopping enjoyment and online purchase intention among women in Malaysia.

\section{Literature Review}

\section{Impulsive Buying Behaviour}

Impulsive buying is normally caused by the emotional or psychological influences which stimulate the consumer to make a spontaneous purchase to fulfil an urge (Weinberg \& Gottwald 1982). The 
consumer will simply buy a product or service which they did not intend to buy in the first place. A study by Rook (1987) does not agree that impulse purchase is stimulated by a specific factor, but it occurs when consumers experience a sudden urge and therefore will perform an impulsive purchase without any additional evaluation. According to Piron (1991), the impulsive purchase is an unplanned action that stimulated by other factors and it happens when a consumer makes the decision to buy a product on the "spur-of-the-moment". However, Park and Kim (2008), found that the impulsive buying tendency can be planned and reminded. Besides, his study found that hedonic consumption has a significant relationship with impulsive buying tendency whereby positive emotion will affect the impulsive buying tendency. The higher emotional activation (i.e. enjoyment) will have less cognitive control, and this will generate a higher impulsive purchase tendency. "Impulse shoppers tend to be more emotional than non-shoppers" (Weinberg \& Gottwald, 1982: pp.52). A significant difference between women and men were found and women tend to have irresistible impulse to buy and positive buying emotion towards an online purchase if compared with men. According to Burgess (2003), women are easier to be influenced by affective and cognitive factors in performing an impulsive purchase. "Impulse buying of the shopper is influenced by a number of factors which could be either related to the shopping environment, shopper's personal traits, product itself and the diverse demographic and socio-cultural aspects" (Bhakat \& Muruganantham, 2013: pp.152). The study indicated that impulsive buying tendency can stimulate the interaction of various internal (Personality traits) and external (socio-culture traits). In order to generate a better understanding on the impulsive buying tendency as it addresses the role of situational and socio-demographic attributes of high impulsive buying tendency consumers compared to low impulsive buying tendency consumers, a study was conducted by Styven et al., (2017). In this study, the finding indicates the high impulsive tendency on average is more frequent among female online shoppers and with higher levels of trust on the internet. On the other hand, low impulsive tendency shoppers will tend to abandon their online shopping carts often due to uncertainty on the internet because of the lack of confident to purchase online.

\section{Perceived Risk}

Consumer perceived risk was founded by Bauer (1960) in marketing literature to measure the attitude towards a purchase. The concept proposed that "Consumer behavior involves risk in the sense that any action of a consumer will produce consequences which he cannot anticipate with anything approximating certainty, and some of which at least are likely to be unpleasant" (Bauer, 1960: pp.75). Now, this topic was extended to a wider discussion and led to numerous inclusive definitions. However, most of the past researches about perceived risk were mainly focused on traditional physical business activities and purchase situation. According to Noort, Kerkhof, and Fennis (2007), there is a huge difference if we compare shopping in a virtual environment to shopping in stores because online shopping only can offer the benefits of convenience, time and financial savings but on the other hand, it will increase the additional perceived risks which are not encountered in normal physical marketplaces. This notion was further supported by Forsythe and Shi (2003) because their study indicated that in the online shopping environment, limited physical access to the products and sales personnel will exaggerate the level of perceived risk. Besides, consumers' beliefs on the possible doubtful negative consequences from online transaction is defined as the 
perceived risk based on the information communicated on the website regarding the security of customers' personal information and other security concerns in the transaction which will normally create a perception of the level of risk with an e-commerce business activity (Kim et al., 2008). Bhatnagar, Misra, and Rao (2000) have discussed three types of risks namely financial risk, product risk, and information risk. Financial risk involves the opportunity cost and time and mostly it will happen because of the marketing channel. Product risk describes the product appearance, features, and performance which might be different than how it has been displayed and described on a website. On the other hand, information risk involves transaction security and privacy during online transactions. Park and John (2010) have further added to the existing list of types of risk. They identified an additional two major types of risk: i. behavioral risk and ii. environment risk. The former type of risk stresses those online retailers who try to gain the benefits from reserving the information will affect the effectiveness of the online transaction which will result in behavioral risk in ecommerce. On the other hand, the latter explains that "impulsive nature of the purchase standard will cause the environment risk" (Park \& John, 2010: pp. 659). Therefore, in online shopping, retailers and consumers are exposed to the various types of risks which are difficult to be controlled and monitored. Hence, it is evident that perceived risk has a strong influence to online purchase decision as consumers may feel reluctant to make an online purchase when the sense of risk is overwhelming compared with brick-and-mortar shopping mode (Kim et al., 2008). Nevertheless, Lim and Dubinsky (2005) mentioned that the perceived risk level of a consumer is based on the efforts of safeguarding their personal information and the security of the online transaction.

\section{Shopping Enjoyment}

The impulsive purchase most likely will happen when a consumer enjoys shopping for his/her own benefits or interests. A "recreational shopper" will spend relatively more time for shopping and continue shopping even after they have completed the purchase (Bush \& Grant 1995). Some of the past research argued that recreational shoppers prefer to spend more time on window shopping or browsing around and do not have an intention for purchase (Karande \& Ganesh, 2000). According to Ingham, Cadieux, and Berrada (2015), consumers will enjoy a perceived pleasure from the website experience and this experience will increase the activities of online purchase. This was evident in a study by Seock and Bailey (2008) who found that consumers will search for information about the product online before purchase indicating a significant relationship between shopping orientations with the time spend on browsing online which is more prevalent among female shoppers compared to male. Based on this research, female shoppers tend to get "hedonic" enjoyment such as excitement during the shopping experience which Wang, Yeh, and Liao (2013) proved in their research in establishing a significant relationship between perceived enjoyment, perceived value, and purchase intention. Nevertheless, these findings were contradictory to research by Ling et al., (2010), Cai and Xu (2006) and Verhoef and Langerak (2001) who proved that shopping enjoyment and online purchase intention does not have significant association in the web purchase environment. The literature argues that shopping enjoyment may be a function of gender and therefore cannot be generalized across all type of online shoppers. For instance, Otnes and Mcgrath (2001) and Stern (1999) recognized that gender plays an important role in defining shopping behaviors. According to Hart et al. (2007), men have a stronger relationship of enjoyment with re-patronage if compared with 
INTERNATIONAL JOURNAL OF ACADEMIC RESEARCH IN BUSINESS AND SOCIAL SCIENCES Vol. 9, No. 7, July, 2019, E-ISSN: 2222-6990 @ 2019 HRMARS

women and this has only created a further argument in view of gender and shopping enjoyment. There are many theoretical reasons to show that women may have different shopping enjoyment if compare with men.

\section{Online Purchase Intention}

Purchase intention is the plan to buy a specific product or service within a designated period (Hajli et al., 2017). A decision to buy a particular product or brand by the consumer was defined as purchase intention (Shah et al., 2012). "The online shopping process involves an exchange of time, effort and money for the receipt of products or services in a virtual store" (Wu, 2013: pp. 167). According to the study by Boster et al., (2014), the theory of reasoned action (TRA) can be an influential explanation of the process that determines peoples' intentional behavior. Normally most of the people will consider the consequences that their actions will have before they decide to perform any action "The theory of reasoned action is used in order to predict a person's intention to behave in a certain way, this is done by evaluating a person's attitude towards a specific behaviour as well as the subjective norms of influential people and groups that could affect the person's attitude" (Boster et al., 2014: pp.713). According to Zarrad (2012), online purchase of consumer is affected by internal and external motivations during the buying process. Martínez-López et al., (2015) identified trust and perceived usefulness of the recommender as the key factors in explaining the consumer's online purchase intention. According to another research conducted by Soto-Acosta et al, (2014), the information on the website will also affect the online shoppers' purchase intention. They argued that disorganized and overload of information will affect the internet experience of online shoppers and eventually it will affect the online purchase intention which Gogoi (2013) cautioned as misled purchase decisions. While online security remains as one of the major concerns in online purchase intentions, a psychological approach is needed to influence the consumer process of adoption and use the recommended information in online purchase intention (Martínez-López et al., 2015) driven by online trust (Eslami \& Imomoh, 2016; Thamizhvanan, 2013) which will affect fairness and distributive fairness (Chou, 2012). This is because “Consumers' actual buying behavior is dichotomous because consumers either have to purchase or not purchase the item" (Lee \& Lee, 2015: pp. 61). Online retailers need to explore the impact of shopping behaviors on customer online purchase intention because consumers' perception of "justice" is an important and unique consideration in online shopping (Wu, 2013).

\section{Hypotheses Development}

\section{Impulsive Buying Behaviour and Online Purchase Intention}

The higher emotional activation will have less cognitive control, and this will generate a higher impulsive purchase tendency. "Impulse shoppers tend to be more emotional than non-shoppers" (Weinberg \& Gottwald, 1982: pp. 52). According to Verplanken and Herabadi (2001), an impulsive purchase involves spontaneous purchase without thoughtful consideration. Research shows that online shoppers are more likely to be impulsive judged against traditional shoppers (Donthu, 1999). Therefore, when female consumers spend more time browsing the website, the impulsive buying tendency will increase their online purchase intention. This is because online shoppers like to browse the website to get product information and they will do more unplanned purchase compared with 
INTERNATIONAL JOURNAL OF ACADEMIC RESEARCH IN BUSINESS AND SOCIAL SCIENCES

Vol. 9, No. 7, July, 2019, E-ISSN: 2222-6990 ¿C 2019 HRMARS

traditional shopping due to the impulsive buying tendency. Therefore, the following hypothesis was formulated:

$\mathrm{H} 1$ : There is a significant relationship between impulsive buying tendency and online shopping intention.

\section{Perceived Risk and Online Purchase Intention}

Perceived risk has a strong influence on the online purchase decision as consumers feel reluctant to make an online purchase when the sense of risk is overwhelming compared with brick-and-mortar shopping mode (Kim et al., 2008). Based on the literature review, the perceived risk factor is found to be one of the important factors that influence an individual's decision to engage in online purchases. According to Theory of Reasoned Action (TRA), the consumer will perform a trusting attitude on certain object/environment where he/she believe in and eventually he/she will form an intention to behave and react to that object/environment. This intention will be the prime determinant of actual behavior (Ajzen, 1991). TRA articulates that perceived risk represents the cognitive factor that might affect the online purchase intention of the consumer. If the consumer has a lower trust level towards e-commerce, it causes a negative influence on the perceived risk. That means a lower trust level will have a higher perceived risk to e-commerce and eventually will reduce the online purchase intention (Featherman et al., 2010). On this ground, the following hypothesis was formulated:

$\mathrm{H} 2$ : There is a significant relationship between perceived risk and online shopping intention.

\section{Shopping Enjoyment as Mediator}

According to Ingham, Cadieux, and Berrada (2015), consumers will have a perceived pleasure and enjoyment from the website experience and this experience will increase the activities of online purchase. Research by Wang, Yeh and Liao (2013) found that perceived enjoyment has a significant influence on perceived value and this has a further positive effect on purchase intention. With the forming of hypotheses on the relationship between impulsive buying intention and online purchase intention, shopping enjoyment envisaged being a mediating factor on the relationship between impulsive buying tendency and online purchase intention. Thus, based on these arguments, the following hypotheses were formulated:

H3: There is a mediating effect of shopping enjoyment on the relationship between impulsive buying tendency and online shopping intention.

H4: There is a mediating effect of shopping enjoyment on the relationship between perceived risk and online shopping intention. 
INTERNATIONAL JOURNAL OF ACADEMIC RESEARCH IN BUSINESS AND SOCIAL SCIENCES

Vol. 9, No. 7, July, 2019, E-ISSN: 2222-6990 @ 2019 HRMARS

\section{Conceptual Framework}

The theoretical framework of the study is shown in Figure 1. There will be two independent variables which are impulsive buying tendency and perceived risk and one dependent variable namely online purchase intention. This relationship is further mediated by shopping enjoyment.

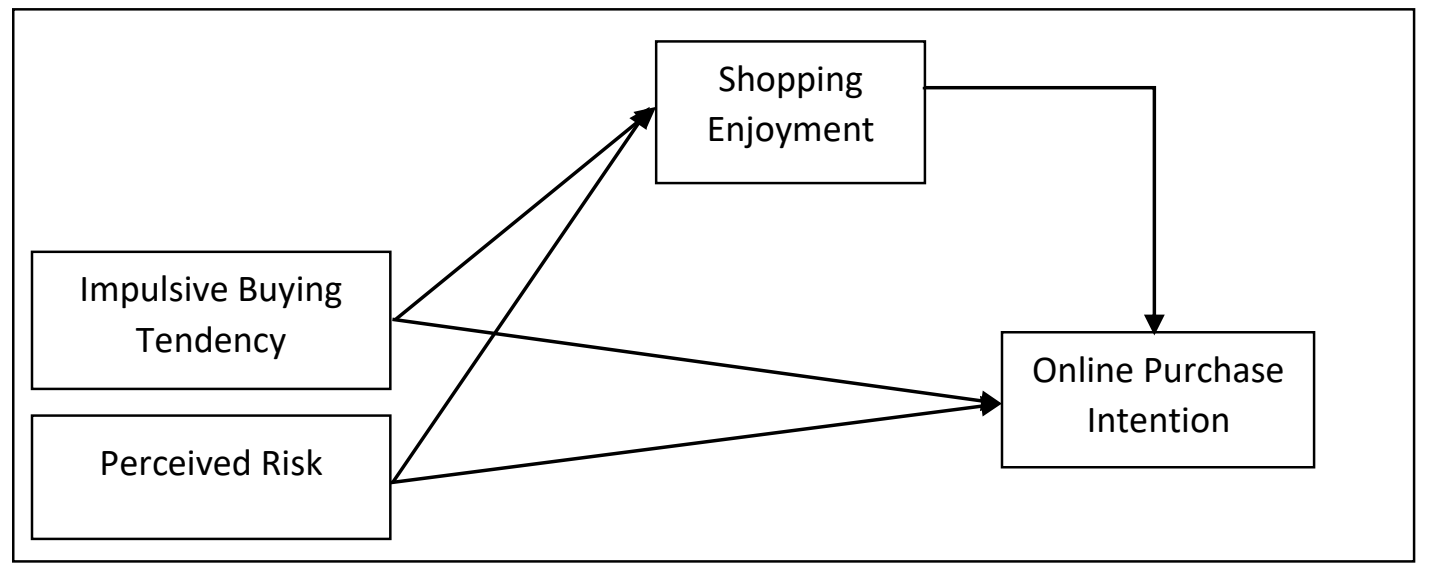

Figure 1: Conceptual Framework

\section{Research Methodology \\ Sample and Data Collection}

The sample size intended for this research consist of Malaysian women in the age group of 19 to 49 years old. The geography of this study covers the whole of Malaysia. Considering the population size, the minimum required sample size was 384 respondents. In this study, simple random sampling was used to collect the data. With this method, elements of each population able to identify and each of them has an equal possibility being selected (Zikmund, 2003). This study employed a quantitative research method. The data for the research was collected through an online questionnaire to improve the reachability of the respondents across the country. This method was chosen because is more cost saving, less time consuming and more convenient to distribute. Besides, the online survey method allows better privacy control which allows more open response (Sproull \& Kiesler, 1986).

\section{Measures and Instrumentation}

The measurement which was adopted for this research was a 5 point Likert scale. 5-point Likert scale was chosen because, according to an empirical study done on Likert scale levels, it was found that 5 or 7 levels tend to produce slightly higher mean scores compared to 10 levels (Dawes, 2002). On the other hand, the test instrumentation used for this research was adapted from previous studies. The instrumentations used in this research are as stated in Table 1. 
INTERNATIONAL JOURNAL OF ACADEMIC RESEARCH IN BUSINESS AND SOCIAL SCIENCES

Vol. 9, No. 7, July, 2019, E-ISSN: 2222-6990 @ 2019 HRMARS

Table 1: Test Instruments

\begin{tabular}{llc}
\hline Author & Construct & Number of Items \\
\hline $\begin{array}{l}\text { Badgaiyan, Verma, and Dixit } \\
\text { (2016) }\end{array}$ & $\begin{array}{l}\text { Impulsive Buying } \\
\text { Tendency }\end{array}$ & 10 \\
\hline Shareef et al. (2011) & Perceived Risk & 6 \\
\hline Seock and Bailey (2008) & Shopping Enjoyment & 5 \\
\hline Gefen and Straub (2004) & $\begin{array}{l}\text { Online Purchase } \\
\text { Intention }\end{array}$ & 3 \\
\hline
\end{tabular}

\section{Findings and Discussion}

\section{Research Sample Analysis}

A valid 358 respondents were finalized for the study after omitting respondents with missing and outliers. The research sample analysis of the respondents is displayed in Table 2.

Table 2: Research Sample Analysis

\begin{tabular}{|l|l|r|r|}
\cline { 2 - 4 } \multicolumn{1}{c|}{} & Category & Frequency & Percentage \\
\hline \multirow{4}{*}{ Age } & Below 21 & 99 & $27.65 \%$ \\
\cline { 2 - 4 } & $21-30$ & 132 & $36.87 \%$ \\
\cline { 2 - 4 } & $31-40$ & 102 & $28.50 \%$ \\
\cline { 2 - 4 } & $41-50$ & 13 & $3.63 \%$ \\
\cline { 2 - 4 } Income & Above 50 & 12 & $3.35 \%$ \\
\cline { 2 - 4 } & Below RM2000 & 27 & $7.54 \%$ \\
\cline { 2 - 4 } & RM2001-RM4000 & 96 & $26.82 \%$ \\
\cline { 2 - 4 } & RM4001-RM6000 & 122 & $34.08 \%$ \\
\cline { 2 - 4 } & RM6001-RM8000 & 85 & $23.74 \%$ \\
\cline { 2 - 4 } & Above RM8000 & 28 & $7.82 \%$ \\
\hline Education & Secondary school & 51 & $14.25 \%$ \\
\cline { 2 - 4 } & Diploma/STPM & 116 & $32.40 \%$ \\
\cline { 2 - 4 } & Degree & 133 & $37.15 \%$ \\
\cline { 2 - 4 } & Master & 57 & $15.92 \%$ \\
\cline { 2 - 4 } & PhD & 1 & $0.28 \%$ \\
\hline
\end{tabular}

Based on Table 2, a total of 99 respondents are below 20 years old, while 132 respondents are between 21 to 30 years followed by 31 years old to 40 years old, 102 respondents. Besides that, a total of 122 respondents fall into the middle-income group which is between RM4001 and RM6000 per month. The lowest respondent's rate is from income group above RM8000 per month. In terms of educational level, most respondents are degree holders which comprise of 133 respondents while respondents holding diploma made up of 116 respondents. 
INTERNATIONAL JOURNAL OF ACADEMIC RESEARCH IN BUSINESS AND SOCIAL SCIENCES

Vol. 9, No. 7, July, 2019, E-ISSN: 2222-6990 @ 2019 HRMARS

\section{Reliability Analysis}

There are two types of validity, internal and external. The internal validity test refers to the validity of the measurement and test itself, whereas external validity is referring to the ability to generate the findings from the target population. Both tests are equally important in analyzing the appropriateness, meaningfulness, and usefulness of the data (Psucd, 2011). The reliability can be defined as consistency, stability, and repeatability of results. The main purpose of the reliability test is to ensure that consistent results will be obtained in an identical situation on different occasions (Twycross \& Shields, 2004). The most common method applied to measure the internal consistency will be Cronbach Coefficient Alpha $(\alpha)$ which was developed by Lee Cronbach in 1951 which range between 0 and 1 . According to Malhotra (2004), if the coefficient alpha value is at least 0.60 , internal consistency reliability is within the satisfaction level.

Table 3: Reliability Results of Survey Instrument

\begin{tabular}{|l|c|}
\hline Variables under investigation & Cronbach Alpha \\
\hline Impulsive Buying Tendency (IBT) & 0.929 \\
\hline Perceived Risk (PR) & 0.812 \\
\hline Shopping Enjoyment (SE) & 0.854 \\
\hline Online Purchase Intention (OPI) & 0.929 \\
\hline
\end{tabular}

Based on Table 3, the Cronbach coefficient was between 0.812 and 0.929 which is more than 0.60 as defined by Malhotra (2004). The result shows that the test instrument has an adequate level of internal consistency.

\section{Sample Adequacy}

Kaiser-Meyer-Olkin (KMO) test was conducted to measure the sampling adequacy (Thompson, 2004). On the other hand, Bartlett's test of Sphericity was carried out to test whether a significant interrelationship exists between variables under study (Field, 2009). The results of these tests are reported in Table 4:

Table 4: Measure of Sampling Adequacy

\begin{tabular}{|l|l|r|}
\hline \multicolumn{2}{|c|}{ KMO and Bartlett's Test } \\
\hline $\begin{array}{l}\text { Kaiser-Meyer-Olkin Measure of Sampling } \\
\text { Adequacy. }\end{array}$ & .919 \\
\hline \multirow{2}{*}{$\begin{array}{l}\text { Bartlett's Test } \\
\text { of Sphericity }\end{array}$} & Approx. Chi-Square & 4484.898 \\
\cline { 2 - 3 } & df & 276 \\
\cline { 2 - 3 } & Sig. & .000 \\
\hline
\end{tabular}

Both KMO and Bartlett's test of Sphericity was closer to 1 and significant respectively. Therefore, the data was confirmed to be appropriate for Exploratory Factor Analysis (EFA). 
INTERNATIONAL JOURNAL OF ACADEMIC RESEARCH IN BUSINESS AND SOCIAL SCIENCES Vol. 9, No. 7, July, 2019, E-ISSN: 2222-6990 @ 2019 HRMARS

\section{Exploratory Factor Analysis}

According to Rummel (1970), factor analysis is important to test whether variables in the study can be reduced to a smaller set of latent variables with an assumption that a linear relationship exists between the variables tested (Gorsuch, 1983). The correlation of the components should be .30 or greater because if the correlation of components is lower than .30, it indicates a weak relationship between the variables (Tabachnick and Fidell, 2007). Therefore, an EFA is important to identify the structure of factors which are investigated in a study (Abdul-Halim and Che-Ha, 2009). EFA is a test where measurable and observable variables of a study are reduced to a lesser latent variable which has the same variances through the process called dimension reduction (Rietveld \& van Hout, 1993). Hence, a Principal Component Analysis (PCA) employing varimax rotation was performed. Table 5 provides the results of the analysis.

Table 5: Variables, Items, and Factor Loadings

\begin{tabular}{|c|c|c|}
\hline Variables & Items & $\begin{array}{l}\text { Factor } \\
\text { Loading }\end{array}$ \\
\hline \multirow[t]{10}{*}{ IBT } & IBT1. I usually think carefully before I buy something. & .862 \\
\hline & IBT2. I usually only buy things that I intend to buy. & .878 \\
\hline & IBT3. If I buy something I usually do that spontaneously. & .780 \\
\hline & IBT4. Most of my purchases are planned in advance. & .837 \\
\hline & IBT5. I only buy things that I really need. & .808 \\
\hline & IBT6. I often buy things without thinking. & .844 \\
\hline & $\begin{array}{l}\text { IBT7. I sometimes buy things because I like buying things, } \\
\text { rather than because I need them. }\end{array}$ & .790 \\
\hline & $\begin{array}{l}\text { IBT8. I sometimes cannot suppress the feeling of wanting } \\
\text { things I see in shops. }\end{array}$ & .759 \\
\hline & IBT9. I am a bit reckless about buying things. & .710 \\
\hline & IBT10. I usually think carefully before I buy something. & .862 \\
\hline \multirow[t]{6}{*}{ PR } & $\begin{array}{l}\text { PR1. Providing credit card information through the website is } \\
\text { riskier. }\end{array}$ & .659 \\
\hline & $\begin{array}{l}\text { PR2. I am concerned about the privacy of my personal } \\
\text { information during a transaction. }\end{array}$ & .418 \\
\hline & $\begin{array}{l}\text { PR3. Purchasing from a website would involve more product } \\
\text { risk when compared with more traditional ways of } \\
\text { shopping }\end{array}$ & .689 \\
\hline & $\begin{array}{l}\text { PR4. Purchasing from the website would involve more } \\
\text { financial risk when compared with more traditional ways } \\
\text { of shopping. }\end{array}$ & .730 \\
\hline & $\begin{array}{l}\text { PR5. How would you rate your overall perception of risk from } \\
\text { the website? }\end{array}$ & .765 \\
\hline & $\begin{array}{l}\text { PR6. The web vendor will use my personal information for } \\
\text { other purposes without my authorization. }\end{array}$ & .478 \\
\hline
\end{tabular}


INTERNATIONAL JOURNAL OF ACADEMIC RESEARCH IN BUSINESS AND SOCIAL SCIENCES Vol. 9, No. 7, July, 2019, E-ISSN: 2222-6990 @ 2019 HRMARS

\begin{tabular}{|c|c|c|}
\hline Variables & Items & $\begin{array}{l}\text { Factor } \\
\text { Loading }\end{array}$ \\
\hline \multirow[t]{5}{*}{ SE } & SE1. I enjoy shopping for cosmetic products online & .814 \\
\hline & $\begin{array}{l}\text { SE2. Shopping cosmetic products online provides me with a } \\
\text { lot of enjoyment }\end{array}$ & .815 \\
\hline & I enjoy browsing for Products or services online & .731 \\
\hline & SE4. $\quad$ Shopping for clothes puts me in a good mood & .745 \\
\hline & SE5. I enjoy spending time browsing for products or services & .833 \\
\hline \multirow[t]{3}{*}{ OPI } & OPI1. I am likely to purchase the products(s) on this site. & .858 \\
\hline & OPI2. I am likely to recommend this site to my friends. & .846 \\
\hline & $\begin{array}{l}\text { OPI3. I am likely to make another purchase from this site if I } \\
\text { need the products that I will buy. }\end{array}$ & .852 \\
\hline
\end{tabular}

All the items resulted in a factor loading in the range of 0.418 and 0.878 . This is well above a threshold level of 0.30 as recommended by Tabachnick and Fidell (2007).

\section{Results of the Tests of the Hypotheses}

The research tested the direct relationships of Impulsive Buying Tendency and Perceived Risk towards Online Purchase Intention. Additionally, a mediating effect of shopping enjoyment was also tested against these relationships. The results of hypotheses testing are shown in Table 6, Table 7, and Table 8.

Table 6: Hypotheses Test Results

\begin{tabular}{|c|c|c|c|c|c|c|}
\hline H & Relationship & Std. $\boldsymbol{\beta}$ & t-value & $\begin{array}{c}\text { Sig. (p- } \\
\text { value) }\end{array}$ & $\mathbf{R}^{\mathbf{2}}$ & Result \\
\hline H1 & IBT $\rightarrow$ OPI & 0.193 & 4.301 & 0.000 & 0.322 & Significant \\
\hline H2 & PR $\rightarrow$ OPI & -0.026 & -0.744 & 0.457 & -0.026 & Insignificant \\
\hline
\end{tabular}

Based on Table 6, the t-value is 4.301 while the $p$-value is $0.000<0.05$. This result shows that hypothesis $\mathrm{H} 1$ is supported and a significant relationship is found between impulsive buying tendency and online purchase intention. The standardized beta value of 0.193 shows that there is sufficient support that impulsive buying tendency positively influences online purchase intention. Hence $\mathrm{H} 1$ was accepted. Next, the relationship between perceived risk and online purchase intention was tested. The $t$-value is -0.744 while the $p$-value is $0.457>0.05$. This result shows that an insignificant relationship is found between perceived risk and online purchase intention. Nevertheless, the standardized beta value of -0.026 shows that there is a negative association between perceived risk influencing online purchase intention. As a result, hypothesis $\mathrm{H} 2$ was rejected.

According to Baron and Kenny (1986), to determine the relationship of multiple variables with a mediating factor normally is a four-step regression analysis approach to examine the significance of the coefficients obtained at each step. For Step 1-3, the main purpose is to ensure there is a zeroorder relationship among the variables tested. The mediation is not possible if there is one for more 
INTERNATIONAL JOURNAL OF ACADEMIC RESEARCH IN BUSINESS AND SOCIAL SCIENCES

Vol. 9, No. 7, July, 2019, E-ISSN: 2222-6990 @ 2019 HRMARS

than one of the relationship are insignificant in Step 1-3 (Mackinnon, Fairchild and Fritz, 2007). For Step 4, if the mediator factor, shopping enjoyment is significant after controlling independent variable impulsive buying tendency, it means a partial mediation was supported. Meanwhile, a full mediation is supported if impulsive buying tendency is no longer significant when shopping enjoyment is controlled.

Table 7: Mediation Effect (IBT-OPI)

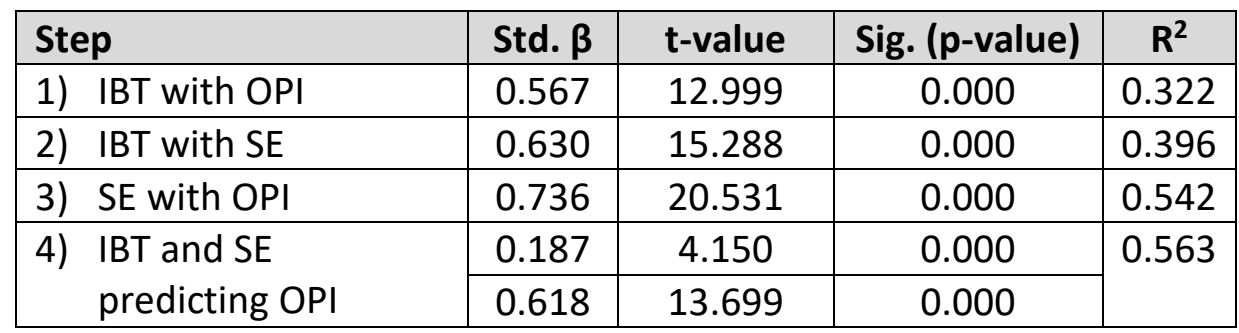

Based on Table 7, all steps 1 to 3 were found to be significant, $p<0.05$ and have allowed mediation testing in Step 4. In step 4, both the impulsive buying tendency and shopping enjoyment variable remain significant, $p<0.001$ which concludes that a partial mediation exists.

Table 8: Mediation Effect (PR-OPI)

\begin{tabular}{|l|c|c|c|c|}
\hline Step & Std. $\boldsymbol{\beta}$ & $\mathbf{t}$-value & Sig. (p-value) & $\mathbf{R}^{\mathbf{2}}$ \\
\hline 1) PR with OPI & 0.055 & 1.036 & 0.301 & 0.003 \\
\hline
\end{tabular}

Based on Table 8, in step 1, the relationship between perceived risk and online purchase intention is found to be insignificant because the $p$-value $0.301>0.05$. Since the first step of mediation analysis failed, subsequence steps of mediation analysis were not performed. Therefore, it was concluded that there is no mediating effect of shopping enjoyment on the relationship between perceived risk and online purchase intention.

Table 9: Summary of Hypotheses

\begin{tabular}{|c|c|}
\hline Hypothesis & Result \\
\hline $\begin{array}{r}\mathrm{H} 1 \text { : There is a significant relationship between impulsive buying } \\
\text { tendency and online purchase intention }\end{array}$ & Accepted \\
\hline $\begin{array}{r}\mathrm{H} 2 \text { : There is a significant relationship between perceived risk and online } \\
\text { purchase intention }\end{array}$ & Rejected \\
\hline $\begin{array}{r}\text { H3: There is a mediating effect of shopping enjoyment between } \\
\text { impulsive buying tendency and online purchase intention }\end{array}$ & $\begin{array}{c}\text { Accepted } \\
\text { (Partial Mediation) }\end{array}$ \\
\hline $\begin{array}{r}\mathrm{H} 2 \text { : There is a mediating effect of shopping enjoyment between } \\
\text { perceived risk and online purchase intention }\end{array}$ & $\begin{array}{c}\text { Rejected } \\
\text { (No Mediation) }\end{array}$ \\
\hline
\end{tabular}


INTERNATIONAL JOURNAL OF ACADEMIC RESEARCH IN BUSINESS AND SOCIAL SCIENCES

Vol. 9, No. 7, July, 2019, E-ISSN: 2222-6990 @ 2019 HRMARS

\section{Discussion}

\section{Impulsive Buying Tendency and Online Purchase Intention}

The purpose of this hypothesis is to determine the relationship between impulsive buying tendency and online purchase intention. Based on the results, it was concluded that there is a significant relationship between impulsive buying tendency and online purchase intention. The result of this study indicates that the higher the impulsive buying tendency, the higher the respondents intention to purchase products or services online. This is in line with research findings by Zhang et al. (2007) who concluded that impulse purchase is positively related to the customer online purchase intention. Similar findings were reported by Donthu and Garcia (1999) who asserts that online shoppers were more likely to be impulse oriented. According to the finding of another research by Ozen and Engizek, (2014), most of the online consumers will perceive online shopping as an adventurous activity and they will feel relax when they are browsing websites or purchase products or services online. According to Piron (1991), the impulsive purchase is an unplanned action that stimulates by other factors and it happens when consumer make the decision to buy a product on the "spur-of-themoment". Dittmar et al, (1995) provided further support that women are easily influenced by impulse buying.

\section{Perceived Risk and Online Purchase Intention}

It was concluded that perceived risk is not significantly related to online purchase intention. This research finding indicates that perceived risk does not affect the online purchase intention because most of the respondents apparently do not perceive online purchase as risky when they purchase a product or service online. This could be attributed to the wide-ranging perspectives about perceived risk and its acceptance level because the understanding of perceived risk is very subjective. Although the hypothesis was insignificant, Kim et al., (2008) and Salisbury et al., (2001) reported similar association (i.e. perceived risk is negatively associated with online purchase intention) that perceived risk negatively related to online purchase intention inferring that high perceived risk will reduce the online purchase intention and vice versa. Nevertheless, if the online retailers can provide sufficient information on their websites (Soto-Acosta et al., 2014) and comprehensive structure of a website (Lurie, 2004), the online consumers will have reduced uncertainty and lower perceived risk. Apart from that, assurance of privacy of personal and financial information while shopping online will reduce concerns over online purchases (Harn et al., 2006).

\section{Mediating Effect of Shopping Enjoyment}

Based on the statistical analysis, a partial mediating effect of shopping enjoyment was evident in the relationship between impulsive buying tendency and online purchase intention. The findings indicate that shopping enjoyment contributes partially to how impulsive buying tendency could affect online purchase intention. Park and Kim (2008) found that the hedonic consumption has a significant relationship with impulsive buying tendency whereby positive emotion will affect online purchase intention. According to Ingham, Cadieux, and Berrada, (2015), consumers will have a perceived pleasure and enjoyment from the website experience and this experience will increase the activities of online purchase. According to the research conducted by Weinberg and Gottwald (1982), higher emotional activation will have less cognitive control, and this will generate a higher impulsive 
purchase tendency. Another research finding by $\mathrm{Yu}$ and Bastin (2010) revealed that shopping enjoyment or any activities that make a consumer feel happy and relax will lead to impulsive buying tendency and the relationship are inextricably related to each other and females tend to get "hedonic" enjoyment such as excitement during the shopping experience. This is further agreed by Wang et al., (2013) informing that perceived enjoyment has a significant influence on perceived value and this has a further positive effect on purchase intention. Nevertheless, there is no mediation effect of shopping enjoyment on the relationship between perceived risk and online purchase intention. Since risk is not proven to be a factor contributing to the online purchase intentions, it was inferred that risk does not affect the enjoyment of a consumer while browsing online to purchase products and services.

\section{Conclusion}

With the rapid growth of e-commerce worldwide, it is very important to understand more about the factors that influence consumers' online purchase intention. The findings of this study have found that there is, in fact, a significant relationship between impulsive buying tendency and online purchase intention while shopping enjoyment is found to have a partial mediating effect on the relationship.

This study offered some theoretical contributions. According to the Theory of Planned Behaviour (TPB) which was formulated by Ajzen, TPB was an extension of the Theory of Reasoned Action (TRA) which included the measures of control belief and perceived behavioral control (Armitage \& Conner, 2001). The core value of both theories claimed that human will analyze the available information on hand and make a logical, reasoned decision to engage in specific behaviors. In this study, it was proven that consumers will make an impulsive purchase with the stimulation effect of shopping enjoyment. While many research reports a positive association between impulsive buying and purchase intention, Ling et al., (2010) stated otherwise that shopping enjoyment does not have a positive relationship with purchase intention in the web purchase environment. In view of varying findings, Chang et al. (2011) concluded that existing researches have reported inconsistencies in the study of impulsive buying and purchase intentions. Therefore, this study has offered some direction to this phenomenon. Additionally, several researchers (e.g. Pavlou, 2003; Crespo et al., 2009; Hsu et al., 2014) indicated that perceived risk or online trust needs further research in understanding consumers' online purchase intention. This indicates that risk should be investigated in regards to specific phenomena as it can result in different findings.

In terms of managerial implications, the findings from this study could be useful for existing e-retailers or who are considering starting their online business. The finding in this study can let e-retailers to have a better understanding about the importance of shopping enjoyment and how to improve the shopping experience through their websites and eventually stimulate online purchase intention among women in Malaysia. The results of this study revealed that the respondents will engage in online purchase impulsively most of the time, hence e-retailer can use this finding to improve the website design to make it more attractive and user-friendly. Besides, e-retailers can stimulate the impulse buying desire and behavior among consumers by creating promotional activities with a focus 
INTERNATIONAL JOURNAL OF ACADEMIC RESEARCH IN BUSINESS AND SOCIAL SCIENCES Vol. 9, No. 7, July, 2019, E-ISSN: 2222-6990 @ 2019 HRMARS

on fun, excitement, and variety. Furthermore, this study could provide policymakers a better understanding of enhancing the security on the e-commerce platforms and to design efficient rules and regulations.

\section{Limitations and Recommendation for Future Research}

Though the study provides some directions into consumer research, it still suffers a few limitations. The first limitation of this study is the sample of the study which is limited to women consumers only which means the finding of this research does not represent overall online consumers behaviors in Malaysia. Incorporation of male online consumers in the study will enhance the generalizability and have comparative findings of online consumers' behaviors in Malaysia. Secondly, the study used several variables only namely impulsive buying tendency, perceived risk, and shopping enjoyment to explain online purchase intention phenomenon. Since consumer research is a wide area, inclusions of other relevant variables would increase the predictive ability of this research. The last limitation will be the language constraints of a questionnaire which limits to English only. This might have discounted other relevant and suitable respondents who are not conversant with the English language.

Due to the limitations of this research, there are three recommendations suggested for future research for enhancement of the study of the customers' online purchase intention. The first recommendation is to include more dimensions of consumers' shopping orientations in explaining the phenomenon. It could further evaluate the impacts of impulsive buying tendency, perceived risk and shopping enjoyment on online purchase intention for existing and potential customers who have a strong intention to participate in the online purchase transaction. By doing so, it could provide more clarity into more dimensions of shopping orientation individually which could ultimately explain online purchase intention in a more comprehensive manner. The second recommendation is to extend the study for the male online shoppers in Malaysia to get a comprehensive picture of online purchase behaviors. Addition of male online shoppers will provide comparative findings, providing clarity into gender-specific online purchase intention debates.

\section{References}

Abdul-Halim, H., \& Che-Ha, N. (2009). Testing the Dimensionality of Integrated HRM Strategy among Malaysian Manufacturing Organizations. International Journal of Business and Management, 4(10), 120-134.

Ajzen, I. (1991). The theory of planned behavior. Organizational Behavior and Human Decision Processes, 50(2), 179-211.

Armitage, C. J., \& Conner, M. (2001). Efficacy of the Theory of Planned Behaviour: A meta-analytic review. British Journal of Social Psychology, 40(4), 471-499.

Badgaiyan, A. J., Verma, A., \& Dixit, S. (2016). Impulsive buying tendency: Measuring important relationships with a new perspective and an indigenous scale. IIMB Management Review, 28(4), 186-199. Bandura, A. (1982). Self-efficacy mechanism in human agency. American Psychologist, 37(2), 122-147. 
INTERNATIONAL JOURNAL OF ACADEMIC RESEARCH IN BUSINESS AND SOCIAL SCIENCES

Vol. 9, No. 7, July, 2019, E-ISSN: 2222-6990 @ 2019 HRMARS

Baron, R. M., \& Kenny, D. A. (1986). The moderator-mediator variable distinction in social psychological research: Conceptual, strategic, and statistical considerations. Journal of Personality and Social Psychology, 51(6), 1173-1182.

Bauer, R. (1960). Consumer behavior as risk taking. Dynamic Marketing for a Changing World (pp. 389-398). Chicago: American Marketing Association.

Bhakat, R. S., \& Muruganantham, G. (2013). A Review of Impulse Buying Behavior. International Journal of Marketing Studies, 5(3), 149-160.

Bhatnagar, A., Misra, S., \& Rao, H. R. (2000). On risk, convenience, and Internet shopping behavior. Communications of the ACM, 43(11), 98-105.

Boster, F. J., Shaw, A. Z., Carpenter, C. J., \& Lindsey, L. L. (2014). Simulation of a Dynamic Theory of Reasoned Action. Simulation \& Gaming, 45(6), 699-731.

Burgess, A. C. (2003). Gender differences in cognitive and affective impulse buying. Journal of Fashion Marketing and Management, 7(3), 282-295.

Bush, A. J., \& Grant, E. S. (1995). The Potential Impact of Recreational Shoppers on Mall Intercept Interviewing: An Exploratory Study. Journal of Marketing Theory and Practice, 3(4), 73-83.

Cai, S., \& Xu, Y. (2006). Effects of outcome, process and shopping enjoyment on online consumer behaviour. Electronic Commerce Research and Applications, 5(4), 272-281.

Chang, H., Eckman, M., \& Yan, R. (2011). Application of the Stimulus-Organism-Response model to the retail environment: The role of hedonic motivation in impulse buying behavior. The International Review of Retail, Distribution and Consumer Research, 21(3), 233-249.

Chou, Y. T. C. Y. (2012). Exploring the continuance intentions of consumers for B2C online shopping. Online Information Review, 36(1), 104-125.

Child, D. (2006). The essentials of factor analysis. (3rd ed.). New York, NY: Continuum International Publishing Group.

Cohen, J. (1988). Statistical power analysis for the behavioral sciences (2nd ed.). Hillsdale, NJ: Lawrence Erlbaum Associates.

Crespo, Á H., Bosque, I. R., \& M. M., \& Sánchez, D. D. L. S. (2009). The influence of perceived risk on Internet shopping behavior: A multidimensional perspective. Journal of Risk Research, 12(2), 259-277.

Dawes, J. G. (2002). Five point vs. eleven point scales: does it make a difference to data characteristics? Australasian Journal of Market Research, 10 (1), 39 - 47.

Dittmar, H., Beattie, J., \& Friese, S. (1995). Gender identity and material symbols: Objects and decision considerations in impulse purchases. Journal of Economic Psychology, 16(3), 491-511.

Donthu, N. and Garcia, A. (1999). The internet shopper', Journal of Advertising Research, 39(3), 5258.

Eslami, M., \& Imomoh, E. (2016). Trust in online futures market: A study of Malaysia. Qualitative Research in Financial Markets, 8(2), 118-129.

Featherman, M. S., Miyazaki, A. D., \& Sprott, D. E. (2010). Reducing online privacy risk to facilitate eservice adoption: The influence of perceived ease of use and corporate credibility. Journal of Services Marketing, 24(3), 219-229.

Field, A. (2009). Discovering Statistics Using SPSS: Introducing Statistical Method (3rd ed.). Thousand Oaks, CA: Sage Publications. 
INTERNATIONAL JOURNAL OF ACADEMIC RESEARCH IN BUSINESS AND SOCIAL SCIENCES

Vol. 9, No. 7, July, 2019, E-ISSN: 2222-6990 @ 2019 HRMARS

Forsythe, S. M., \& Shi, B. (2003). Consumer patronage and risk perceptions in Internet shopping. Journal of Business Research, 56(11), 867-875.

Piron, F. (1991). Defining Impulse Purchasing. Retrieved from Advances in Consumer Research: http://acrwebsite.org/volumes/7206/volumes/v18/NA-18

Gefen, D., \& Straub, D. W. (2004). Consumer trust in B2C e-Commerce and the importance of social presence: Experiments in e-Products and e-Services. Omega, 32(6), 407-424.

Gogoi, B. J. (2013). Study of Antecedents of Purchase Intention and its Effect on Brand Loyalty of Private Label Brand of Apparel. International Journal of Sales and Marketing Management, 3(2), 73-86.

Gorsuch, R. L. (1983). Factor analysis (2nd ed.). Hillside, NJ: Lawrence Erlbaum Associates.

Hajli, N., Sims, J., Zadeh, A. H., \& Richard, M. (2017). A social commerce investigation of the role of trust in a social networking site on purchase intentions. Journal of Business Research, 71(1), 133141.

Harn, A. C., Khatibi, A., \& Ismail, H. B. (2006). E-Commerce: A Study on Online Shopping in Malaysia. Journal of Social Sciences, 13(3), 231-242.

Hart, C., Farrell, A. M., Stachow, G., Reed, G., \& Cadogan, J. W. (2007). Enjoyment of the Shopping Experience: Impact on Customers Repatronage Intentions and Gender Influence. The Service Industries Journal, 27(5), 583-604.

Houda Zarrad, M. D. (2012). Online Purchasing Intention: Factors and Effects. International Business and Management, 4(1), 37-47.

Hsu, M., Chuang, L., \& Hsu, C. (2014). Understanding online shopping intention: The roles of four types of trust and their antecedents. Internet Research, 24(3), 332-352.

Ingham, J., Cadieux, J., \& Berrada, A. M. (2015). E-Shopping acceptance: A qualitative and metaanalytic review. Information \& Management, 52(1), 44-60.

Karande, K., \& Ganesh, J. (2000). Who Shops at Factory Outlets and Why?: An Exploratory Study. Journal of Marketing Theory and Practice, 8(4), 29-42.

Kim, D. J., Ferrin, D. L., \& Rao, H. R. (2008). A trust-based consumer decision-making model in electronic commerce: The role of trust, perceived risk, and their antecedents. Decision Support Systems, 44(2), 544-564.

Lee, J., \& Lee, J. (2015). How purchase intention consummates purchase behaviour: The stochastic nature of product valuation in electronic commerce. Behaviour \& Information Technology, 34(1), 57-68.

Likert, R. (1932). A technique for the measurement of attitudes. Archives of Psychology, 22 (140), 555.

Lim, H., \& Dubinsky, A. J. (2005). The theory of planned behavior in e-commerce: Making a case for interdependencies between salient beliefs. Psychology and Marketing, 22(10), 833-855.

Ling, K. C., Chai, L. T., \& Piew, T. H. (2010). The Effects of Shopping Orientations, Online Trust and Prior Online Purchase Experience toward Customers' Online Purchase Intention. International Business Research, 3(3), 63-75.

Lurie, N. H. (2004). Decision Making in Information-Rich Environments: The Role of Information Structure. Journal of Consumer Research, 30(4), 473-486. 
INTERNATIONAL JOURNAL OF ACADEMIC RESEARCH IN BUSINESS AND SOCIAL SCIENCES

Vol. 9, No. 7, July, 2019, E-ISSN: 2222-6990 @ 2019 HRMARS

MacKinnon, D. P., Fairchild, A. J., \& Fritz, M. S. (2007). Mediation analysis. Annual Review of Psychology, 58(1), 593-614.

Malhotra, N. K. (2004). Marketing Research. Prentice Hall, New Jersey

Martínez-López, F. J., Esteban-Millat, I., Cabal, C. C., \& Gengler, C. (2015). Psychological factors explaining consumer adoption of an e-vendor's recommender. Industrial Management \& Data Systems, 115(2), 284-310.

Mottain, M. (2017). Malaysia in the new economy. Retrieved from The Star Onine: https://www.thestar.com.my/business/business-news/2017/02/04/malaysia-in-the-neweconomy/

Noort, G. V., Kerkhof, P., \& Fennis, B. M. (2007). Online versus Conventional Shopping: Consumers Risk Perception and Regulatory Focus. CyberPsychology \& Behavior, 10(5), 731-733.

Otnes, C., \& Mcgrath, M. A. (2001). Perceptions and realities of male shopping behavior. Journal of Retailing, 77(1), 111-137.

Ozen, H., \& Engizek, N. (2014). Shopping online without thinking: Being emotional or rational? Asia Pacific Journal of Marketing and Logistics, 26(1), 78-93.

Park, E., \& Kim, E. (2008). Effects of Consumer Tendencies and Positive Emotion on Impulse Buying Behavior for Apparel. Journal of the Korean Society of Clothing and Textiles, 32(6), 980-990.

Park, J. K., \& John, D. R. (2010). Got to Get You into My Life: Do Brand Personalities Rub Off on Consumers? Journal of Consumer Research, 37(4), 655-669.

Pavlou, P. A. (2003). Consumer acceptance of electronic commerce: Integrating trust and risk with the technology acceptance model. International Journal of Electronic Commerce, 7(3), 101-134.

Psucd. (2011). What is validity and why is it important in research? Retrieved from Word Press: https://psucd8.wordpress.com/2011/11/20/why-is-validity-important-in-research.

Rietveld, T., \& van Hout, R. (1993). Statistical techniques for the study of language and language behaviour. Berlin: Mouton de Gruyter

Rook, D. W. (1987). The Buying Impulse. Journal of Consumer Research, 14(1), 189-199.

Rummel, R. J. (1970). Applied factor analysis. Evanston, IL: Northwestern University Press.

Salisbury, W. D., Pearson, R. A., Pearson, A. W. \& Miller D. W. (2001). Perceived security and World Wide Web purchase intention. Industrial Management \& Data Systems, 101, 165-176.

Seock, Y., \& Bailey, L. R. (2008). The influence of college students shopping orientations and gender differences on online information searches and purchase behaviours. International Journal of Consumer Studies, 32(2), 113-121.

Shah, S. S. H., Aziz, J., Jaffari, A. R., Waris, S., Ejaz, W., Fatima, M., \& Sherazi, S. K. (2012). The impact of brands on consumer purchase intentions. Asian Journal of Business Management, 4(2), 105110.

Shareef, M. A., Kumar, V., Kumar, U., \& Dwivedi, Y. K. (2011). e-Government Adoption Model (GAM): Differing service maturity levels. Government information quarterly, 28(1), 17-35.

Soto-Acosta, P., Molina-Castillo, F. J., Lopez-Nicolas, C., \& Colomo-Palacios, R. (2014). The effect of information overload and disorganisation on intention to purchase online. Online Information Review, 38(4), 543-561.

Sproull, L., \& Kiesler, S. (1986). Reducing Social Context Cues: Electronic Mail in Organizational Communication. Management Science, 32(11), 1492-1512. 
INTERNATIONAL JOURNAL OF ACADEMIC RESEARCH IN BUSINESS AND SOCIAL SCIENCES

Vol. 9, No. 7, July, 2019, E-ISSN: 2222-6990 @ 2019 HRMARS

Statistics, I. W. (2017). Asia Internet Use, Population Data and Facebook Statistic. Retrieved from Internet World Stats Usage and Population Statistics:

http://www.internetworldstats.com/stats3.htm\#asia

Stern, B. B. (1999). Gender and Multicultural Issues in Advertising: Stages on the Research Highway. Journal of Advertising, 28(1), 1-9.

Styvén, M. E., Foster, T., \& Wallström, Å. (2017). Impulse buying tendencies among online shoppers in Sweden. Journal of Research in Interactive Marketing, 11(4), 416-431.

Tabachnick, B. G., \& Fidell, L. S. (2007). Using multivariate statistics (5th ed.). Boston, MA: Allyn \& Bacon.

Thamizhvanan, A., \& Xavier, M. (2013). Determinants of customers online purchase intention: An empirical study in India. Journal of Indian Business Research, 5(1), 17-32.

Thompson, B. (2004). Exploratory and confirmatory factor analysis: Understanding concepts and applications. Washington, DC, US: American Psychological Association.

Twycross, A., \& Shields, L. (2004). Validity and reliability - What's it all about? Paediatric Nursing, 16(10), 36-36.

Verhoef, P. C., \& Langerak, F. (2001). Possible determinants of consumers' adoption of electronic grocery shopping in the Netherlands. Journal of Retailing and Consumer Services, 8(5), 275-285.

Verplanken, B., \& Herabadi, A. (2001). Individual differences in impulse buying tendency: Feeling and no thinking. European Journal of Personality, 15(S1), 71-83.

Wang, Y., Yeh, C., \& Liao, Y. (2013). What drives purchase intention in the context of online content services? The moderating role of ethical self-efficacy for online piracy. International Journal of Information Management, 33(1), 199-208.

Weinberg, P., \& Gottwald, W. (1982). Impulsive consumer buying as a result of emotions. Journal of Business Research, 10(1), 43-57.

Wolfer, L. T. (2007). Real research: conducting and evaluating research in the social sciences. Boston: Pearson/Allyn and Bacon.

$\mathrm{Wu}$, I. (2013). The antecedents of customer satisfaction and its link to complaint intentions in online shopping: An integration of justice, technology, and trust. International Journal of Information Management, 33(1), 166-176.

Yu, C., \& Bastin, M. (2010). Hedonic shopping value and impulse buying behavior in transitional economies: A symbiosis in the Mainland China marketplace. Journal of Brand Management, 18(2), 105-114.

Zhang, X., Prybutok, V., \& Strutton, D. (2007). Modeling Influences on Impulse Purchasing Behaviors During Online Marketing Transactions. The Journal of Marketing Theory and Practice, 15(1), 7989.

Zikmund, W. G. (2003). Business research methods. Mason, OH : South-Western Cengage Learning. 